\title{
Synthesis of Metal Oxides@C (Metal=Ni, Fe) Based Prussian Blue Analogs as a High-performance Anode Material for Lithium-ion Battery
}

\author{
Wei Yang ${ }^{1} \cdot$ Xiaoxian Pang $^{1} \cdot$ Zhao Xue $^{2} \cdot$ Jinhao Ye $^{1} \cdot$ Haosen Fan $^{1} \cdot$ Ting Shu $^{3} \cdot$ Wenzhi Zheng $^{1} \cdot$ Shengzhou Chen $^{1}$
}

Received: 9 October 2020 / Revised: 24 December 2020 / Accepted: 8 January 2021 / Published online: 25 February 2021

(c) The Chinese Society for Metals (CSM) and Springer-Verlag GmbH Germany, part of Springer Nature 2021

\begin{abstract}
$\mathrm{Ni}_{3}\left[\mathrm{Fe}(\mathrm{CN})_{6}\right]_{2}$ nano-cubic precursors were prepared by chemical coprecipitation at room temperature with nickel acetate and potassium ferricyanide as raw materials. The corresponding $\mathrm{NiFe}_{2} \mathrm{O}_{4}-\mathrm{NiO} @ \mathrm{C}$ composites with excellent crystallization were prepared by two-stage oxidation at low temperature. The microstructure and electrochemical behavior of the materials showed that the Prussian blue analog was transformed into metal oxide while the carbon coating was maintained in the twostage oxidation at low temperature. The existence of the carbon coating reduces the charge transfer impedance to $31.5 \Omega$. At the current density of $500 \mathrm{~mA} / \mathrm{g}$, the reversible capacity of $632.7 \mathrm{mAh} / \mathrm{g}$ is maintained after 500 cycles. At the same time, carbon cladding can also enhance the role of pseudocapacitance in the material. At the scanning rate of $0.1 \mathrm{mV} / \mathrm{s}$, the pseudocapacitance account for $54.4 \%$ of the total discharge capacity, which is significantly higher than that of uncoated materials.
\end{abstract}

Keywords Lithium-ion battery $\cdot$ Anode materials $\cdot$ Metal oxide $\cdot$ Prussian blue

\section{Introduction}

Owing to eco-friendly, high energy density and long cycling stability without memory effect, lithium-ion batteries (LIB) have been extensively used as rechargeable energy storage systems for portable electronic devices and electric vehicles. However, with the improvement of performance requirements for electronic products, LIB has been unable to satisfy the requirements of higher capacity and energy density due to the low theoretical capacity (about $372 \mathrm{mAh} / \mathrm{g}$ ) of graphite as a positive electrode material [1-3]. Compared with graphite, metal oxide, metal sulfide, metal nitride and

Available online at http://link.springer.com/journal/40195

Wenzhi Zheng

wenzhizheng@gzhu.edu.cn

Shengzhou Chen

szchen@gzhu.edu.cn

1 School of Chemistry and Chemical Engineering, Guangzhou University, Guangzhou 510006, China

2 Patent Examination Cooperation (Henan) Center of the Patent Office, Zhengzhou 450046, China

3 Key Laboratory of Fuel Cell Technology of Guangdong Province, Guangzhou 510640, China other materials have extremely high specific capacity for LIB anode material [4-7]. Based on conversion reaction mechanism of metal oxides has several times theoretical specific capacity more than that of graphite [8-11]. For example, the theoretical specific capacity of $\mathrm{NiO}$ is $731 \mathrm{mAh} / \mathrm{g}$, and the theoretical specific capacities of $\mathrm{FeO}, \mathrm{Fe}_{2} \mathrm{O}_{3}$ and $\mathrm{Fe}_{3} \mathrm{O}_{4}$ are 744, 1007 and $992 \mathrm{mAh} / \mathrm{g}$, respectively [12-15]. These materials have attracted more attention, which makes that one of the important ways to improve the specific capacity of lithium-ion batteries. In addition, iron oxides and manganese oxides also have the advantages of abundant raw materials, low cost, environmental friendliness, and easy recycling and reuse [16].

However, when the transition metal oxide is used as the anode material of lithium-ion battery, the micro-nano structure of metal oxide would change and damage due to the severe volume effect during charge and discharge [17]. Some active materials lose their lithium storage function, and then the specific capacity of the lithium battery decays sharply. This is a major obstacle to the promotion and application of transition metal oxide anode materials. Therefore, alleviating the volume effect of transition metal oxide anode materials during charge and discharge is a pivotal way to further promote the development of lithium-ion batteries [18, 19]. Based on the 
above reasons, in recent years, researchers mainly put forward the design and construction of special structures to achieve this goal. Among them, the widely used ways are to construct hollow structures [20], core-shell structures [21], nanotubes [22], nanoribbons [23] and so on, and the construction of core-shell structures is one of the most effective methods to maintain the structural stability of materials [24]. In addition, due to the poor conductivity of metal oxides, it limits the electrochemical performance as cathode materials of lithium-ion batteries greatly. The researchers combine metal oxides with conductive materials $[19,25]$. In commonly, carbon materials used as composite materials because of the superior electrical conductivity. The composite of transition metal oxides and carbon materials can effectively improve the electrical conductivity of the materials [26-28], and further obtain transition metal oxides/carbon composites with predominant electrochemical properties [29, 30]. Previous studies on the charge storage mechanism in batteries have found that there is an electrochemical behavior of pseudocapacitance during charge and discharge. Pseudocapacitance refers to a supercapacitor in which highly reversible chemical absorption and REDOX reactions occur on the electrode surface, near the surface or in the bulk phase in two or quasi-two dimensions, and the relevant capacitance is generated [31, 32]. In this pseudocapacitive charge storage behavior, the charge is stored on the surface of the material due to the faradaic reactions. Therefore, the study of pseudocapacitance behavior in electrode materials is of great significance for the design and optimization of high-performance electrode materials.

\section{Experimental}

\subsection{Preparation of $\mathrm{NiFe}_{2} \mathrm{O}_{4}-\mathrm{NiO} @ \mathrm{C}$}

In this work, authors used the prepared nanocube as the matrix material, dopamine hydrochloride was polymerized on the surface of the material under the action of tris(hydroxymethyl)aminomethane, and formed a polydopamine (PDA) coating, as shown in Fig. 1. After calcination, the polydopamine layer decomposes into a carbon layer, and the corresponding Prussian blue analogs were transformed into transition metal oxides [33]. We found that the transition metal oxide materials with advantageous crystallization can be obtained by this synthesis method under lower temperature, and the existence of carbon coating greatly increases the proportion of pseudocapacitance contribution in the discharge capacity of the materials. The rate capability and cycle stability of the materials have also been greatly improved.

Prussian blue analog $\mathrm{Ni}_{3}\left[\mathrm{Fe}(\mathrm{CN})_{6}\right]_{2}$ nanocube was prepared by chemical coprecipitation at room temperature. Firstly, $1.2 \mathrm{mmol}$ nickel acetate and $1.6 \mathrm{mmol}$ trisodium citrate were dissolved into $40 \mathrm{ml}$ deionized water. Secondly, $0.8 \mathrm{mmol}$ of potassium ferricyanide was dissolved into $40 \mathrm{ml}$ deionized water, and then slowly dropped into the aforementioned mixed solution of nickel acetate and trisodium citrate at a drop acceleration of $2 \mathrm{ml} / \mathrm{min}$. The solution was thoroughly mixed by continuous stirring during the process. After the dripping was completed, aging for $24 \mathrm{~h}$ at room temperature. Then, it was centrifuged with deionized water and anhydrous ethanol for several times and dried in a vacuum oven at $60{ }^{\circ} \mathrm{C}$ for $10 \mathrm{~h}$. Finally, the orange $\mathrm{Ni}_{3}\left[\mathrm{Fe}(\mathrm{CN})_{6}\right]_{2}$ precursor powder was obtained.

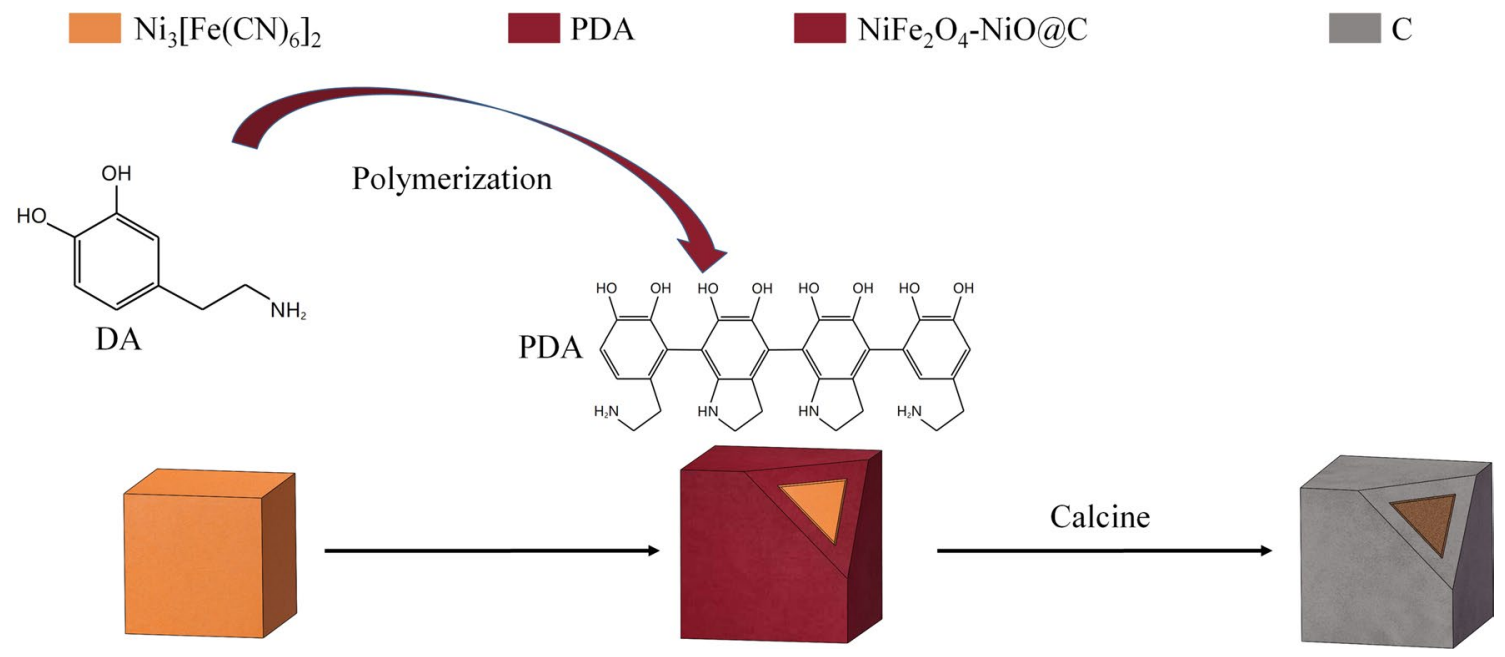

Fig. 1 Preparation process diagram of $\mathrm{NiFe}_{2} \mathrm{O}_{4}-\mathrm{NiO} @ \mathrm{C}$ composite material with core shell structure 
$0.5 \mathrm{~g}$ as-prepared $\mathrm{Ni}_{3}\left[\mathrm{Fe}(\mathrm{CN})_{6}\right]_{2}$ was added into $100 \mathrm{ml}$ deionized water and completely dispersed. $0.121 \mathrm{~g}$ of tris(hydroxymethyl)aminomethane was dissolved in the above dispersion, and then $0.1 \mathrm{~g}$ of dopamine hydrochloride was added, and stirred for $6 \mathrm{~h}$ under $600 \mathrm{r} / \mathrm{min}$ at room temperature. The black red powder $\mathrm{Ni}_{3}\left[\mathrm{Fe}(\mathrm{CN})_{6}\right]_{2} @ \mathrm{PDA}$ material was obtained through centrifugation and washing with deionized water and anhydrous ethanol for several times, drying in the oven at $60^{\circ} \mathrm{C}$ for $10 \mathrm{~h}$.

The prepared $\mathrm{Ni}_{3}\left[\mathrm{Fe}(\mathrm{CN})_{6}\right]_{2} @ \mathrm{PDA}$ material was roasted in a tube furnace for $4 \mathrm{~h}$ at $2{ }^{\circ} \mathrm{C} / \mathrm{min}$ heating rate to $400{ }^{\circ} \mathrm{C}$ in a high-purity nitrogen atmosphere. After natural cooling, it was re-roasted in a muffle furnace at $2{ }^{\circ} \mathrm{C} / \mathrm{min}$ heating rate to $350{ }^{\circ} \mathrm{C}$ in air nitrogen atmosphere for $4 \mathrm{~h}$. Finally, the carbon-coated metal oxide materials $\mathrm{NiFe}_{2} \mathrm{O}_{4}-\mathrm{NiO} @ \mathrm{C}$ was obtained, labeled as NFO@C.

Comparatively, $\mathrm{Ni}_{3}\left[\mathrm{Fe}(\mathrm{CN})_{6}\right]_{2}$ was roasted directly in muff furnace at $600{ }^{\circ} \mathrm{C}$ under air atmosphere for $4 \mathrm{~h}$ to obtain $\mathrm{NiFe}_{2} \mathrm{O}_{4}-\mathrm{NiO}$, labeled as NFO.

\subsection{Electrochemical Measurements}

The prepared $\mathrm{NiFe}_{2} \mathrm{O}_{4}-\mathrm{NiO} @ \mathrm{C}$ and $\mathrm{NiFe}_{2} \mathrm{O}_{4}-\mathrm{NiO}$ materials were assembled to $\mathrm{CR} 2032$ coin cell. The $\mathrm{CR} 2032$ coin cell assembled from working electrode, PP membrane and lithium tablet. The active materials (70 wt $\%)$, super-P (20 wt $\%)$ and polyvinylidene fluoride (PVDF) (10 wt $\%$ ) were ground evenly. The PVDF dissolved in NMP with a mass concentration of $2 \%$ was added. After evenly mixed, the mixture was coated on copper foil to prepare the working electrode. The working electrode was placed in an oven at $60{ }^{\circ} \mathrm{C}$ for $10 \mathrm{~h}$ for preliminary drying. After drying for $24 \mathrm{~h}$ in a vacuum oven at $60{ }^{\circ} \mathrm{C}$, the working electrode was assembled into the coin battery. The dried copper sheet was cut by sheetpunching machine and weighed, and the mass of the active material on the working electrode plate was $1.0-1.5 \mathrm{mg} / \mathrm{cm}^{2}$. The 1.0 $\mathrm{M} \mathrm{LiPF}_{6}$ was dissolved in ethylene carbonate, ethyl methyl carbonate and dimethyl carbonate (volume ratio of $1: 1: 1)$ as the electrolyte. Complete the assembly of the coin battery in the nitrogen environment. Cyclic voltammetry (CV) curves at different scanning rates were measured at an electrochemical workstation (CHI760B electrochemical, China) with potential ranges from 0.01 to $3.00 \mathrm{~V}$ (vs Li/ Li). Cyclic charge and discharge tests and rate capability tests were conducted on the Neware BTS tester. The rate capability experiment was conducted with a step current of $100-5000 \mathrm{~mA} / \mathrm{g}$ (based on the actual mass of the transition metal oxide prepared in the corresponding battery), while the current density of 100 or $500 \mathrm{~mA} / \mathrm{g}$ was used for the cycle performance experiment. Electrochemical impedance spectroscopy (EIS) was conducted with amplitude of $5 \mathrm{mV}$, and the frequency ranging at $0.01-100 \mathrm{kHz}$. The measured data were fitted and analyzed using Zview software.

\subsection{Characterization}

The crystal structure of the prepared samples was analyzed by X-ray powder diffractometer (XRD, XD-3, Beijing Purkinje General, China) with $\mathrm{Cu} \mathrm{K} \alpha$ radiation at $36 \mathrm{kV}$ and $20 \mathrm{~mA}$. Field-emission scanning electron microscopy (FE-SEM, JSM-5600, JEOL, Japan) was used to observe the microstructure of the samples.

\section{Results and Discussion}

Figure 2 shows the XRD diffraction spectrum of the $\mathrm{NiFe}_{2} \mathrm{O}_{4}-\mathrm{NiO} @ \mathrm{C}$ sample. The diffraction peaks at $2 \theta=37.2^{\circ}, 43.3^{\circ}, 62.9^{\circ}$ and $75.4^{\circ}$ are matched with (111), (200), (220) and (311) faces of the standard card PDF\#47$1049 \mathrm{NiO}$, respectively. The diffraction peaks at $2 \theta=30.3^{\circ}$, $35.7^{\circ}$ and $57.4^{\circ}$ are matched with (220), (311) and (511) faces of standard card PDF\#54-0964 $\mathrm{NiFe}_{2} \mathrm{O}_{4}$, respectively. Although the roasting temperature was $350{ }^{\circ} \mathrm{C}$ in the air atmosphere, transition metal oxide crystals were formed in the $\mathrm{NiFe}_{2} \mathrm{O}_{4}-\mathrm{NiO} @ \mathrm{C}$ material. The relatively sharp diffraction peaks demonstrate an excellent crystalline state in the material. These testify that $\mathrm{Ni}_{3}\left[\mathrm{Fe}(\mathrm{CN})_{6}\right]_{2} @ \mathrm{PDA}$ can obtain the corresponding $\mathrm{NiFe}_{2} \mathrm{O}_{4}-\mathrm{NiO}$ material well by calcining in nitrogen at $400{ }^{\circ} \mathrm{C}$ and in air at $350{ }^{\circ} \mathrm{C}$ successively. However, no diffraction peak of $\mathrm{C}$ is found in the XRD pattern, which can be interpreted as the obtained carbon coating is amorphous carbon. The existence of carbon coating layer does not affect the crystal structure of $\mathrm{NiFe}_{2} \mathrm{O}_{4}$ and $\mathrm{NiO}$. In addition, some studies have shown that the presence of carbon coating shorts the path of ion transfer, and its own porous and fluffy structure can provide a larger specific surface area and additional active sites, so that the material shows excellent performance $[21,26]$.

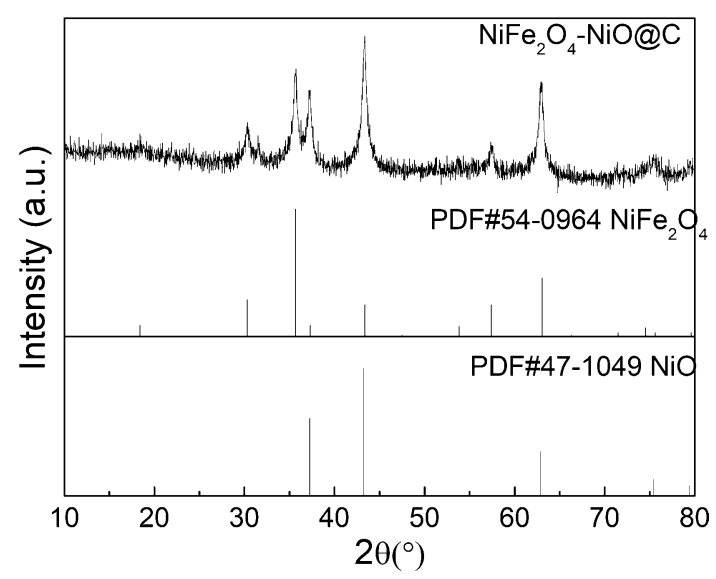

Fig. 2 XRD patterns of $\mathrm{NiFe}_{2} \mathrm{O}_{4}-\mathrm{NiO} @ \mathrm{C}$ sample 
To further characterize the as-prepared materials, the morphology of the materials was investigated by SEM. The pure $\mathrm{Ni}_{3}\left[\mathrm{Fe}(\mathrm{CN})_{6}\right]_{2}$ presents as uniform nanocube particles as shown in Fig. 3a, with a particle size of about $110 \mathrm{~nm}$. The product calcined at $600{ }^{\circ} \mathrm{C}$ still maintains the uniform nano-cubic morphology, but its size shrinks slightly shown in Fig. 3b. After coating PDA, the general morphology of the material does not change, and still maintains the nano-cubic structure shown in Fig. 3c. The particle size of $\mathrm{Ni}_{3}\left[\mathrm{Fe}(\mathrm{CN})_{6}\right]_{2} @ \mathrm{PDA}$ is between 185 and $230 \mathrm{~nm}$. After two-stage calcination at $400{ }^{\circ} \mathrm{C}$ in nitrogen and $350{ }^{\circ} \mathrm{C}$ in air, the material was transformed into $\mathrm{NiFe}_{2} \mathrm{O}_{4}-\mathrm{NiO} @ \mathrm{C}$. There is a depression in the center of the six faces, which is due to the shrinkage of the original nanoparticles after roasting as shown in Fig. $3 \mathrm{~d}$. The polydopamine coating is relatively thick, part of the surface carbon layer is burned. The size of the $\mathrm{NiFe}_{2} \mathrm{O}_{4}-\mathrm{NiO} @ \mathrm{C}$ nanocube seen from the figure is about $200 \mathrm{~nm}$.

The as-prepared $\mathrm{NiFe}_{2} \mathrm{O}_{4}-\mathrm{NiO}$ and $\mathrm{NiFe}_{2} \mathrm{O}_{4}-\mathrm{NiO} @ \mathrm{C}$ were assembled into a button battery with lithium metal sheet to test their electrochemical properties. Figure $4 a, b$ indicates the cyclic voltammetry curve of the two materials at a scanning rate of $0.1 \mathrm{mV} / \mathrm{s}$, and the scanning potential interval is $0.01-3.00 \mathrm{~V}$. These cyclic voltammetry curves can be used to analyze the impact of carbon coating on the electrochemical behavior of $\mathrm{NiFe}_{2} \mathrm{O}_{4}$ and $\mathrm{NiO}$ in materials, and further explain the electrochemical performance of transition metal oxide/carbon composite cells. For $\mathrm{NiFe}_{2} \mathrm{O}_{4}-\mathrm{NiO}$ material, a reduction peak only appeared at $0.42 \mathrm{~V}$ during the first round of scanning, in which $\mathrm{NiO}$ [formula (2)] and $\mathrm{NiFe}_{2} \mathrm{O}_{4}$ [formula (1)] had a reduction reaction [34, 35], and a solid electrolyte interface (SEI) membrane was formed. This potential is mainly determined by the generation
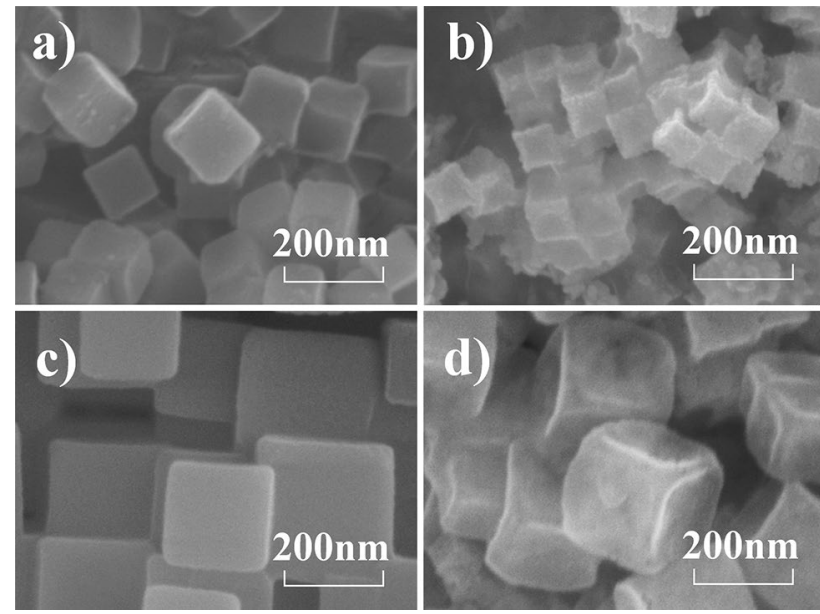

Fig. 3 SEM images: a $\mathrm{Ni}_{3}\left[\mathrm{Fe}(\mathrm{CN})_{6}\right]_{2}$ precusor, b $\mathrm{NiFe}_{2} \mathrm{O}_{4}-\mathrm{NiO}$ calcined at $600{ }^{\circ} \mathrm{C}$ in air; c $\mathrm{Ni}_{3}\left[\mathrm{Fe}(\mathrm{CN})_{6}\right]_{2} @ \mathrm{PDA}$ precusor; d $\mathrm{NiFe}_{2} \mathrm{O}_{4}-\mathrm{NiO} @ \mathrm{C}$ obtained through two-stage low-temperature roasting potential of SEI membrane. In the following oxidation process, two peaks appeared at the positions of 1.65 and $2.26 \mathrm{~V}$, respectively, caused by the oxidation of Fe [formula (5)] and $\mathrm{Ni}$ [formula (4)] [36]. In the second and subsequent reduction process, $\mathrm{NFO}$ has a reduction peak at $0.85 \mathrm{~V}$, and the electrochemical reaction occurring in this process is the reduction of $\mathrm{Fe}_{2} \mathrm{O}_{3}$ [formula (3)] and $\mathrm{NiO}$. Correspondingly, the $\mathrm{NiFe}_{2} \mathrm{O}_{4}-\mathrm{NiO} @ \mathrm{C}$ material also had corresponding electrochemical reactions at various similar potential positions. However, the positions of these peak potentials were all shifted to a certain extent, especially in the discharge process of the first turn, the peak position was shifted downward to $0.31 \mathrm{~V}$, and the peak strength was greatly enhanced. This can be explained as an excellent amorphous carbon coating enhances the growth of SEI membranes during the first discharge, and drag the reduction potential of $\mathrm{NiFe}_{2} \mathrm{O}_{4}$ and $\mathrm{NiO}$ downward [37].

$\mathrm{NiFe}_{2} \mathrm{O}_{4}+8 \mathrm{Li}^{+}+8 \mathrm{e}^{-} \leftrightarrow \mathrm{Ni}+2 \mathrm{Fe}+4 \mathrm{Li}_{2} \mathrm{O}$

$\mathrm{NiO}+2 \mathrm{Li}^{+}+2 \mathrm{e}^{-} \leftrightarrow \mathrm{Ni}+\mathrm{Li}_{2} \mathrm{O}$

$\mathrm{Fe}_{2} \mathrm{O}_{3}+6 \mathrm{Li}^{+}+6 \mathrm{e}^{-} \leftrightarrow 2 \mathrm{Fe}+3 \mathrm{Li}_{2} \mathrm{O}$

$\mathrm{Ni}+\mathrm{Li}_{2} \mathrm{O} \leftrightarrow \mathrm{NiO}+2 \mathrm{Li}^{+}+2 \mathrm{e}^{-}$

$2 \mathrm{Fe}+3 \mathrm{Li}_{2} \mathrm{O} \leftrightarrow \mathrm{Fe}_{2} \mathrm{O}_{3}+6 \mathrm{Li}^{+}+6 \mathrm{e}^{-}$.

$\mathrm{NiFe}_{2} \mathrm{O}_{4}+\mathrm{NiO}+\mathrm{Fe}_{2} \mathrm{O}_{3}+16 \mathrm{Li}^{+}+16 \mathrm{e}^{-} \leftrightarrow 2 \mathrm{Ni}+4 \mathrm{Fe}+8 \mathrm{Li}_{2} \mathrm{O}$.

Meanwhile, in Fig. 4b, the oxidation potential increased to 1.74 and $2.40 \mathrm{~V}$, respectively, corresponding to the oxidation of $\mathrm{Fe}$ and $\mathrm{Ni}$. Similar to the reduction potential of the first turn, the peak is also shifted downward to $0.70 \mathrm{~V}$ in the second turn and the posterior reduction process. The movement of reduction potential to a smaller direction is mainly due to the embedding of lithium ions in the carbon material and the formation of more SEI films, which makes it more difficult for lithium ions generated by $\mathrm{Li}_{2} \mathrm{O}$ inside the material in the process of electrode oxidation to leave, thus pushing up the oxidation potential.

To confirm the rate capabilities of $\mathrm{NiFe}_{2} \mathrm{O}_{4}-\mathrm{NiO}$ and $\mathrm{NiFe}_{2} \mathrm{O}_{4}-\mathrm{NiO} @ \mathrm{C}$ anode materials, cyclic charge and discharge under various current densities in the range of 100-5000 mA/g were conducted. Figure 4c indicates the rate capability curves of the prepared materials, and $\mathrm{NiFe}_{2} \mathrm{O}_{4}-\mathrm{NiO} @ \mathrm{C}$ exhibits better rate capability. The reversible capacities of $\mathrm{NiFe}_{2} \mathrm{O}_{4}-\mathrm{NiO} @ \mathrm{C}$ at current densities of 100, 200, 500, 1000, 2000 and $5000 \mathrm{mAh} / \mathrm{g}$ are 923.9, 852.2, 704.8, 554.5, 396.1 and $193.2 \mathrm{mAh} / \mathrm{g}$, respectively. 


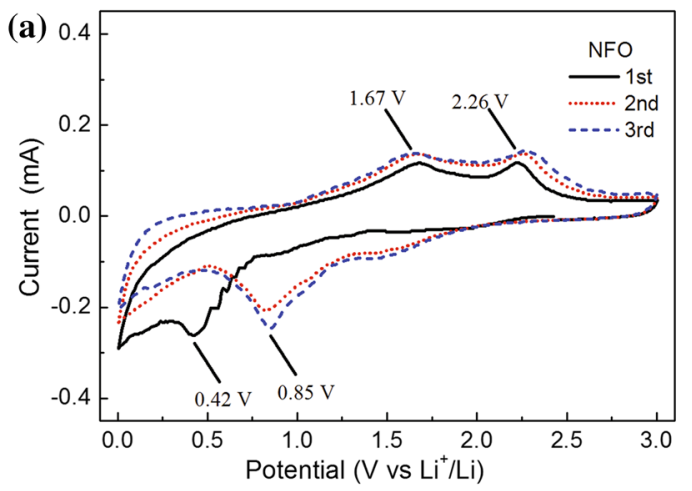

(c)

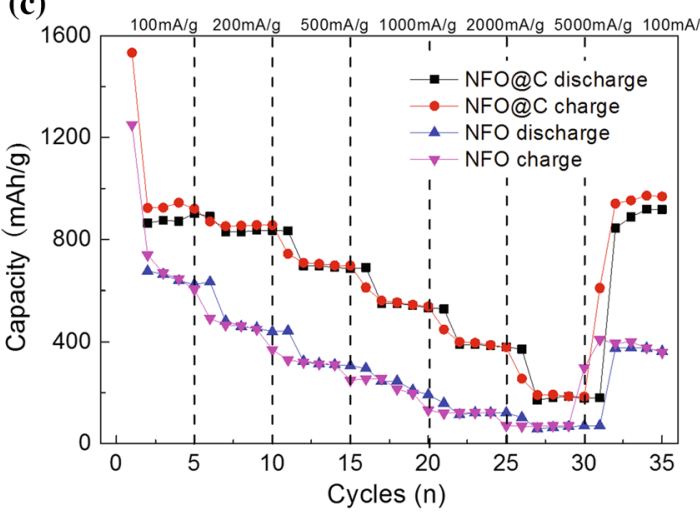

(e)

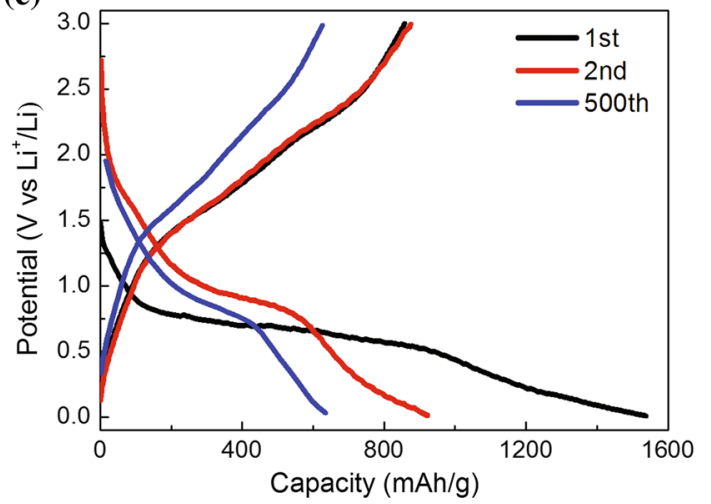

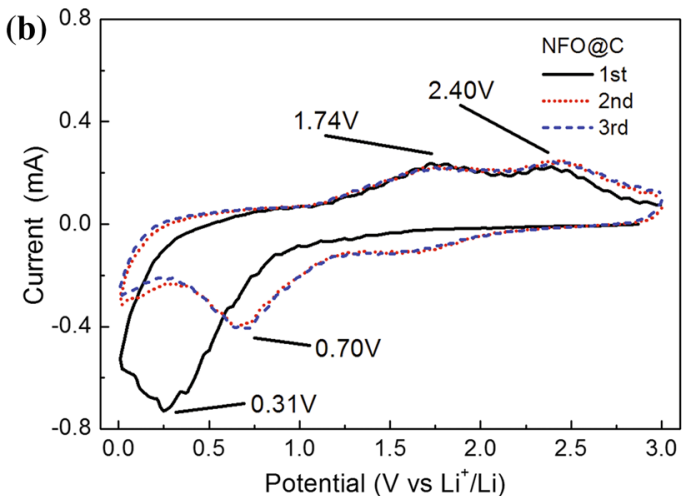

(d)

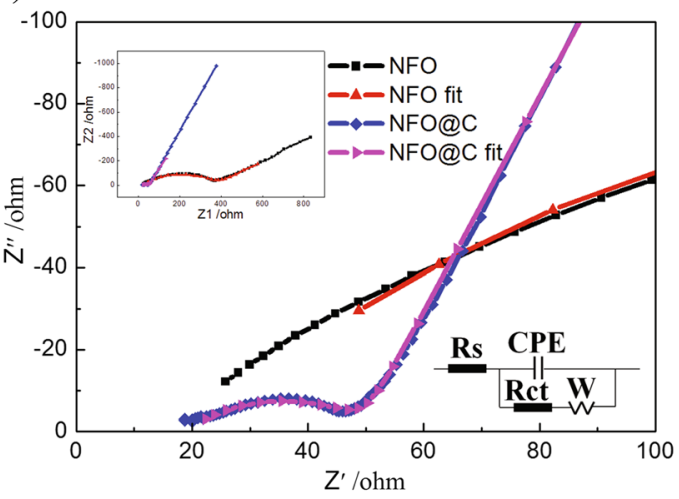

(f)

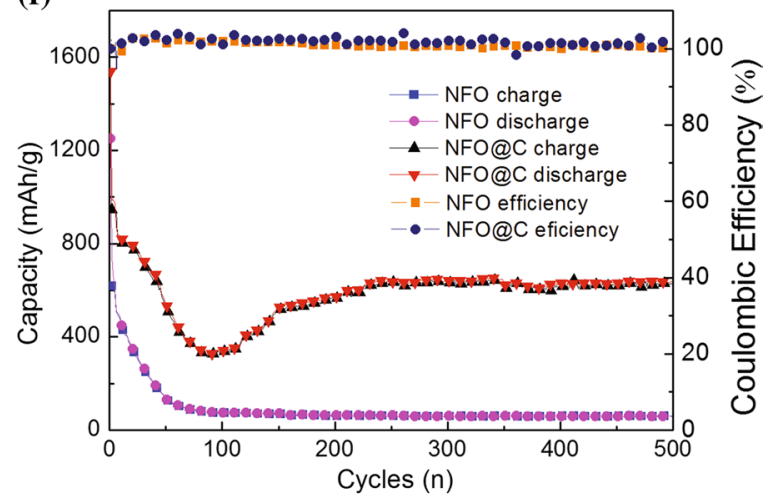

Fig. 4 Cyclic voltammogram curves of $\mathbf{a} \mathrm{NiFe}_{2} \mathrm{O}_{4}-\mathrm{NiO}$ and $\mathbf{b} \mathrm{NiFe}_{2} \mathrm{O}_{4}-\mathrm{NiO} @ \mathrm{C}$ at a scan rate of $0.1 \mathrm{mV} / \mathrm{s}$; $\mathbf{c}$ rate cycle test at various current

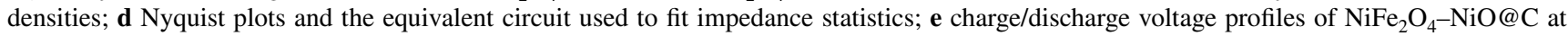
$500 \mathrm{~mA} / \mathrm{g}$ and $\mathbf{f}$ cyclability at $500 \mathrm{~mA} / \mathrm{g}$

The discharge capacity still maintains $953.5 \mathrm{mAh} / \mathrm{g}$ when the current density returns to $100 \mathrm{~mA} / \mathrm{g}$. The coulombic efficiency of $\mathrm{NiFe}_{2} \mathrm{O}_{4}-\mathrm{NiO} @ \mathrm{C}$ is higher than that of $\mathrm{NiFe}_{2} \mathrm{O}_{4}-\mathrm{NiO}$.

In order to further testify the impact of carbon composite on the conductivity of $\mathrm{NiFe}_{2} \mathrm{O}_{4}-\mathrm{NiO} @ \mathrm{C}$, the $\mathrm{AC}$ impedance spectra of the two materials were conducted. The results show AC impedance spectra of both materials consist of a distinct high-frequency semicircle that corresponds to the process of charge transfer, and a straight line at low frequencies that correspond to the diffusion process of lithium ions near the nanoparticles shown in Fig. 4d. Lower charge transfer resistance can improve the diffusion rate and charge transfer rate of lithium ion, thus improving the rate property $[17,18]$. Table 1 demonstrates the corresponding fitting data. Among them, $R_{\mathrm{s}}$ represents the ohmic resistance, $C P E$ and $W$ represent the constant phase angle element and Warburg impedance, respectively, and they are all process parameters fitted by the software Zview. Compared with $\mathrm{NiFe}_{2} \mathrm{O}_{4}-\mathrm{NiO}$, the charge transfer impedance $\left(R_{\mathrm{ct}}\right)$ in the electrochemical reaction process of $\mathrm{NiFe}_{2} \mathrm{O}_{4}-\mathrm{NiO} @ \mathrm{C}$ significantly decreases from 365.6 to $32.1 \Omega$ due to the existence of carbon coating layer. This indicates that in $\mathrm{NiFe}_{2} \mathrm{O}_{4}-\mathrm{NiO} @ \mathrm{C}$ material, the carbon coating and transition metal oxide composite 
Table 1 EIS spectrum fitting data of $\mathrm{NiFe}_{2} \mathrm{O}_{4}-\mathrm{NiO} @ \mathrm{C}$ and $\mathrm{NiFe}_{2} \mathrm{O}_{4}-\mathrm{NiO}$

\begin{tabular}{llllllll}
\hline Samples & $R_{\mathrm{s}}(\Omega)$ & CPE-T & CPE-P & $R_{\mathrm{ct}}(\Omega)$ & $W-R$ & $W-T$ & $W-P$ \\
\hline NFO & 20.3 & $3.2 \times 10^{-5}$ & 0.57 & 365.6 & $2.4 \times 10^{3}$ & $2.8 \times 10^{2}$ & 0.48 \\
NFO@C & 19.2 & $5.6 \times 10^{-7}$ & 0.55 & 32.1 & $4.2 \times 10^{6}$ & $7.1 \times 10^{5}$ & 0.78 \\
\hline
\end{tabular}

material can well integrate the good electrical conductivity advantage of carbon into the transition metal oxide, which greatly reduces the charge transfer impedance of the composite material, and thus greatly improves the rate capability of the composite material.

Figure $4 \mathrm{f}$ shows the cycle stabilities of $\mathrm{NiFe}_{2} \mathrm{O}_{4}-\mathrm{NiO} @ \mathrm{C}$ and $\mathrm{NiFe}_{2} \mathrm{O}_{4}-\mathrm{NiO}$ materials under the long cycle charge-discharge test at $500 \mathrm{~mA} / \mathrm{g}$ current. Figure $4 \mathrm{e}$ shows the corresponding charge-discharge curve. In the test process, the material was activated by 5 cycles of charge and discharge at $100 \mathrm{~mA} / \mathrm{g}$, and then the current density was adjusted to $500 \mathrm{~mA} / \mathrm{g}$. Obviously, the $\mathrm{NiFe}_{2} \mathrm{O}_{4}-\mathrm{NiO} @ \mathrm{C}$ material maintained a higher discharge capacity after 500 cycles, and the final reversible capacity was $632.7 \mathrm{mAh} / \mathrm{g}$, while the $\mathrm{NiFe}_{2} \mathrm{O}_{4}-\mathrm{NiO}$ was only $58.8 \mathrm{mAh} / \mathrm{g}$. During the cycle, the initial discharge capacity of $\mathrm{NiFe}_{2} \mathrm{O}_{4}-\mathrm{NiO} @ \mathrm{C}$ material decreases rapidly due to the change of current density. The subsequent continuous decline is due to the change in the volume of transition metal oxide. Compared with $\mathrm{NiFe}_{2} \mathrm{O}_{4}-\mathrm{NiO}$, the volume change has been weakened on $\mathrm{NiFe}_{2} \mathrm{O}_{4}-\mathrm{NiO} @ \mathrm{C}$ during charging and discharging, because the carbon coating greatly mitigates the pulverization caused by volume change, and stabilize lithiation/ delithiation space. When the cycle reaches around the 100th cycle, its discharge capacity decays to the lowest point and then gradually increases, reaching about $620 \mathrm{mAh} / \mathrm{g}$ at the 232nd cycle, and then maintaining around this capacity until the end of the test. This capacity change is mainly attributed to the structural changes of internal transition metal oxide materials due to volume changes in the early charging and discharging process, as well as the formation of a large number of SEI films. These SEI membranes are essentially passivated layers formed between the electrolyte and the carbon material as a result of electrochemical reaction. The quality of these membranes is closely related to the performance and safety of the battery. The presence of SEI films on composite materials prevents solution co-insertion to a certain extent, and these films adhere to the particles of negative materials, which can expand with the material expansion and effectively alleviate the volume effect in the cycling process [26]. Similar to most transition metal oxide materials, reversible SEI films containing a large number of metallic particles are formed on the surface of the materials. The rapid charging and discharging process contributed by the reversible SEI films is the main reason for pushing up the reversible capacity after 100 cycles. Carbon cladding, on the other hand, provides a stable site for these changes, resulting in a continuously stable capacity and, ultimately, great cyclic stability of $\mathrm{NiFe}_{2} \mathrm{O}_{4}-\mathrm{NiO} @ \mathrm{C}$.

In order to further analyze the electrode dynamics information during the charging and discharging process, several different scanning speeds of $0.1-2.0 \mathrm{mV} / \mathrm{s}$ were selected to test the $\mathrm{CV}$ curve of $\mathrm{NiFe}_{2} \mathrm{O}_{4}-\mathrm{NiO}$ and $\mathrm{NiFe}_{2} \mathrm{O}_{4}-\mathrm{NiO} @ \mathrm{C}$. The test results of $\mathrm{NiFe}_{2} \mathrm{O}_{4}-\mathrm{NiO}$ are shown in Fig. 5a. A reduction peak and two oxidation peaks in the figure increase regularly with the change of scanning rate. Based on the tested CV curve data, formulas (7) and (8) are used to obtain the $b$ value and further fit the contribution ratio of pseudocapacitance in the charging and discharging process [38, 39].

$\log i=b \log v+\log a$.

$i(\mathrm{~V})=k_{1} v+k_{2} v^{1 / 2}$.

By calculating the $b$ values of the three REDOX peaks, it is found that the three $b$ values are all between 0.5 and 1 , which means that the discharge capacity is jointly contributed by capacitor and electrochemical reaction during the charging and discharging process [31]. The $b$ values corresponding to Peak1, Peak2 and Peak3 are $0.62,0.53$ and 0.51 , respectively. By solving the $k_{1}$ and $k_{2}$ in the formula, the performance of the pseudocapacitance at the scanning rate of $0.1 \mathrm{mV} / \mathrm{s}$ is obtained. As shown in Fig. $5 \mathrm{c}$, the shadow part is a fitted CV curve made at the scanning rate of $0.1 \mathrm{mV} / \mathrm{s}$, which accounts for $19.4 \%$ of the real measured CV curve area, which means that the pseudocapacitance contribution accounts for $19.8 \%$ at this scanning rate [32]. Figure $5 \mathrm{~d}$ shows the corresponding pseudocapacitance contribution ratio obtained by fitting at different scanning rates. As the scan rate increases, the reversible capacity of the conversion reaction mechanism in $\mathrm{NiFe}_{2} \mathrm{O}_{4}-\mathrm{NiO}$ materials decreases gradually, so the reversible capacity decreases greatly after increasing the charge-discharge current.

Correspondingly, Fig. 6a shows the $\mathrm{CV}$ curve of $\mathrm{NiFe}_{2} \mathrm{O}_{4}-\mathrm{NiO} @ \mathrm{C}$ at disparate scanning rates, and Fig. 6b shows the fitting of $b$ values of Peak1, Peak2 and Peak3, which are, respectively, 0.82, 0.76 and 0.74 . By solving the $k_{1}$ and $k_{2}$ in the formula, the performance of pseudocapacitance at the scanning rate of $0.1 \mathrm{mV} / \mathrm{s}$ is investigated. As shown in Fig. 6c, the shaded part is the pseudocapacitance contribution of fitting, accounting for $54.4 \%$ of the real measured CV curve area. Figure $6 \mathrm{~d}$ shows the pseudocapacitance contribution ratio of $\mathrm{NiFe}_{2} \mathrm{O}_{4}-\mathrm{NiO} @ \mathrm{C}$ fitted at disparate scanning rates, which is much better than that 

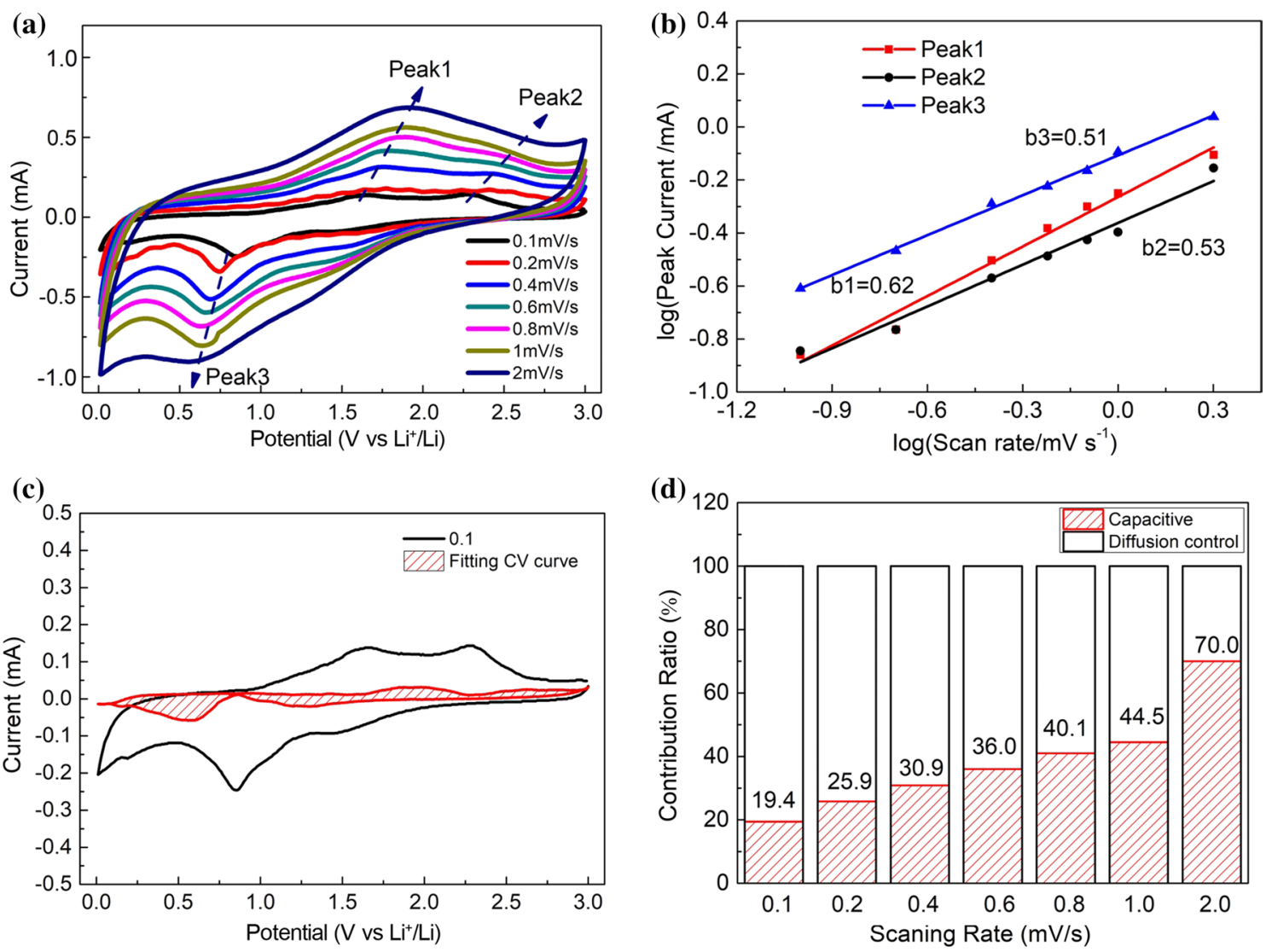

Fig. 5 Kinetics information of working electrode, contribution analysis of pseudocapacitance calculation of $\mathrm{NiFe}_{2} \mathrm{O}_{4}-\mathrm{NiO}$ a cyclic voltammogram curves at various scan rates; $\mathbf{b} b$ value calculation; $\mathbf{c}$ the fitted $\mathrm{CV}$ curves at $0.1 \mathrm{mV} / \mathrm{s} ; \mathbf{d}$ the fitted pseudocapacitance contribution rate at various scan rates

of $\mathrm{NiFe}_{2} \mathrm{O}_{4}-\mathrm{NiO}$. This explains its excellent performance at high current density. The capacity contributed by the pseudocapacitance comes from a rapid charge-discharge process, and at higher charge-discharge currents the pseudocapacitance is less affected than the conversion reaction mechanism. Therefore, the $\mathrm{NiFe}_{2} \mathrm{O}_{4}-\mathrm{NiO} @ \mathrm{C}$ material with more contribution of pseudocapacitance has excellent cyclic stability. The test results effectively show that the composite with carbon materials increases the proportion of capacitive reaction mechanism of $\mathrm{NiFe}_{2} \mathrm{O}_{4}-\mathrm{NiO} @ \mathrm{C}$ in electrochemical reaction. The electrochemical stability of the material at high current density and the reason of capacity attenuation are also explained from another point of view.

\section{Conclusion}

Uniform $\mathrm{Ni}_{3}\left[\mathrm{Fe}(\mathrm{CN})_{6}\right]_{2} @$ PDA nanocube was prepared by selfpolymerization of dopamine on the surface of Prussian blue analog in alkaline aqueous solution. The transition metal oxide carbon composite with good crystallization was prepared by two-stage oxidation at low temperature. The micromorphology and electrochemical performance analysis of the prepared materials showed that the charge transfer impedance of the $\mathrm{NiFe}_{2} \mathrm{O}_{4}-\mathrm{NiO} @ \mathrm{C}$ composite material decreased from 365.6 to $31.5 \Omega$ of the carbon-free cladding material. At the current density of $500 \mathrm{~mA} / \mathrm{g}$, the reversible capacity of the composite material after 500 cycles is maintained at $632.7 \mathrm{mAh} / \mathrm{g}$, while $\mathrm{NiFe}_{2} \mathrm{O}_{4}-\mathrm{NiO}$ only $58.8 \mathrm{mAh} / \mathrm{g}$ is left. Moreover, carbon cladding can also enhance the role of pseudocapacitance in these materials. At the scanning rate of $0.1 \mathrm{mV} / \mathrm{s}$, the composite's pseudocapacitance ratio is $54.4 \%$, which is significantly higher than that of the corresponding uncoated materials. 

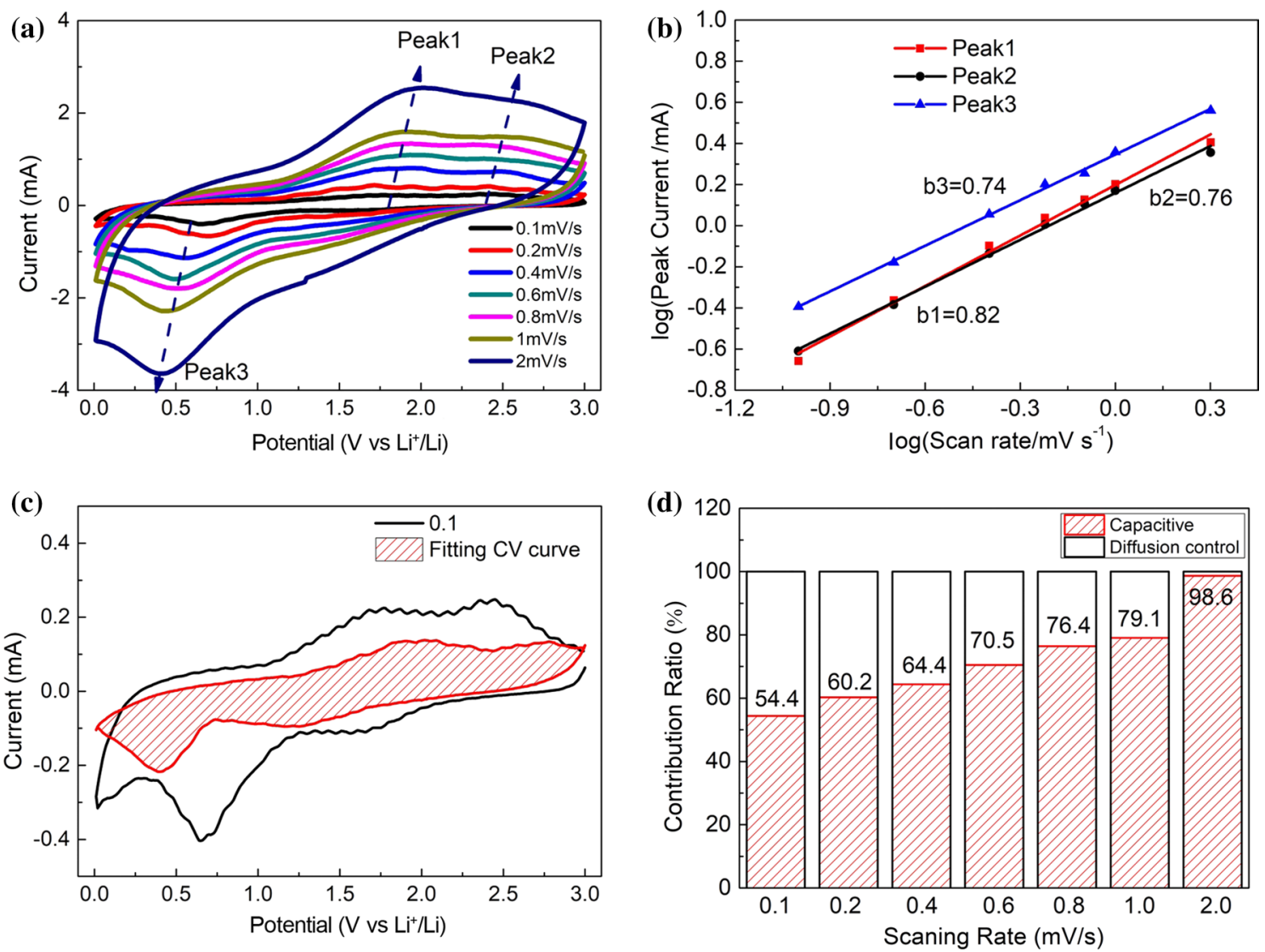

Fig. 6 Kinetics information of working electrode, contribution analysis of pseudocapacitance calculation of $\mathrm{NiFe}_{2} \mathrm{O}_{4}-\mathrm{NiO} @ \mathrm{C}$ : a cyclic voltammogram curves at different scan rates; $\mathbf{b} b$ value calculation; $\mathbf{c}$ the fitted $\mathrm{CV}$ curves at $0.1 \mathrm{mV} / \mathrm{s}$; $\mathbf{d}$ the fitted pseudocapacitance contribution rate at various scan rates

Acknowledgements This work was supported by the National Natural Science Foundation of China (No. 21776051), the Natural Science Foundations of Guangdong (2018A030313423), Guangzhou University Research Projects (YG2020017) and the Research Fund Program of Key Laboratory of Fuel Cell Technology of Guangdong Province.

\section{References}

[1] B. Ding, Z. Cai, Z. Ahsan, Y. Ma, S. Zhang, G. Song, C. Yuan, W. Yang, C. Wen, A review of metal silicides for lithium-ion battery anode application. Acta Metall. Sin.-Engl. Lett. (2020). https:// doi.org/10.1007/s40195-020-01095-Z

[2] Z. Xue, L. Li, L. Cao, W. Zheng, W. Yang, X. Yu, J. Alloys Compd. 825, 153966 (2020)

[3] M. Jiang, M. Jiang, H. Gao, J. Chen, W. Liu, Y. Ma, W. Luo, J. Yang, Comparison of additives in anode: the case of graphene, MXene, CNTs integration with silicon inside carbon nanofibers. Acta Metall. Sin.-Engl. Lett. (2020). https://doi.org/10.1007/ s40195-020-01153-6

[4] A. Eftekhari, Energy Storage Mater. 7, 157 (2017)

[5] Y. Chen, Z. Bi, X. Li, X. Xu, S. Zhang, X. Hu, Electrochim. Acta 224, 534 (2017)

[6] H. Xu, X.D. Zhu, K.N. Sun, Y.T. Liu, X.M. Xie, Adv. Mater. Interfaces 2, 15000239 (2015)
[7] X. Chen, Y. Huang, K. Zhang, X. Feng, M. Wang, Electrochim. Acta 259, 131 (2018)

[8] J. Wu, W. Tu, Y. Zhang, B. Guo, S. Li, Y. Zhang, Y. Wang, M. Pan, Powder Technol. 311, 200 (2017)

[9] X. Shen, Z. Tian, R. Fan, L. Shao, D. Zhang, G. Cao, L. Kou, Y. Bai, J. Energy Chem. 27, 1067 (2018)

[10] Z. Liu, Q. Yu, Y. Zhao, R. He, M. Xu, S. Feng, S. Li, L. Zhou, L. Mai, Chem. Soc. Rev. 48, 285 (2019)

[11] Y. Ding, D. Mu, B. Wu, R. Wang, Z. Zhao, F. Wu, Appl. Energy 195, 586 (2017)

[12] S. Yu, V.M.H. Ng, F. Wang, Z. Xiao, C. Li, L.B. Kong, W. Que, K. Zhou, J. Mater. Chem. A 6, 9332 (2018)

[13] S.L. Zhang, B.Y. Guan, H.B. Wu, X.W. Lou, Nano-Micro Lett. 10, 44 (2018)

[14] J.R. He, L. Luo, Y.F. Chen, A. Manthiram, Adv. Mater. 29, 5 (2017)

[15] L. Zhang, H.B. Wu, X.W. Lou, Adv. Energy Mater. 4, 1300958 (2014)

[16] K. Zhang, S.J. Liang, X.X. Yin, P. Gao, R. Ding, E.H. Liu, J. Electroanal. Chem. 851, 4 (2019)

[17] S. Mohapatra, S.V. Nair, A.K. Rai, Acta Metall. Sin.-Engl. Lett. 31, 164 (2018)

[18] X. Yang, Y.Y. Wang, B.H. Hou, H.J. Liang, X.X. Zhao, H.S. Fan, G. Wang, X.L. Wu, Nano-SnO 2 decorated carbon cloth as flexible, self-supporting and additive-free anode for sodium/lithium-ion 
batteries. Acta Metall. Sin. (Engl. Lett.) (2020). https://doi. org/10.1007/s40195-020-01001-7

[19] K. Cao, T. Jin, L. Yang, L. Jiao, Mater. Chem. Front. 1, 2213 (2017)

[20] J. Tian, Q. Shao, X. Dong, J. Zheng, D. Pan, X. Zhang, H. Cao, L. Hao, J. Liu, X. Mai, Z. Guo, Electrochim. Acta 261, 236 (2018)

[21] X.R. He, Y.J. Zhang, L.F. Yang, J.L. Zhao, H.T. Li, Y.B. Gao, B. Wang, X.D. Guo, Facile fabrication of core-shell structure $\mathrm{Fe}_{3} \mathrm{O}_{4} @ \mathrm{C}$ nanodots for enhanced lithium-sulfur batteries. Acta Metall. Sin.-Engl. Lett. (2020). https://doi.org/10.1007/s4019 5-020-01104-1

[22] Z. Wang, Z. Zhang, J. Xia, W. Wang, S. Sun, L. Liu, H. Yang, J. Alloy. Compd. 769, 969 (2018)

[23] W. Shi, Y. Zhang, J. Key, P.K. Shen, J. Power Sour. 379, 362 (2018)

[24] W. Lu, X. Guo, Y. Luo, Q. Li, R. Zhu, H. Pang, Chem. Eng. J. 355, 208 (2019)

[25] T. Dong, G. Wang, P. Yang, Diam. Relat. Mat. 73, 210 (2017)

[26] S.Z. Liang, X.Y. Wang, Y.G. Xia, S.L. Xia, E. Metwalli, B. Qiu, Q. Ji, S.S. Yin, S. Xie, K. Fang, L.Y. Zheng, M.M. Wang, X.X. Zuo, R.J. Li, Z.P. Liu, J. Zhu, P. Muller-Buschbaum, Y.J. Cheng, Acta Metall. Sin.-Engl. Lett. 31, 910 (2018)

[27] S. Mu, Q. Liu, P. Kidkhunthod, X. Zhou, W. Wang, Y. Tang, Molecular grafting towards high-fraction active nanodots implanted in N-doped carbon for sodium dual-ion batteries. Natl. Sci. Rev. (2020). https://doi.org/10.1093/nsr/nwaa178
[28] F. Dou, L. Shi, G. Chen, D. Zhang, Electrochem. Energy Rev. 2, 149 (2019)

[29] D. Du, W. Yue, X. Fan, K. Tang, X. Yang, Electrochim. Acta 194, 17 (2016)

[30] J. Shao, J. Feng, M. Zhu, H. Zhou, A. Yuan, J. Mater. Sci.-Mater. Electron. 30, 982 (2019)

[31] R. Yang, F. Zhang, X. Lei, Y. Zheng, G. Zhao, Y. Tang, C.S. Lee, A.C.S. Appl, Mater. Interfaces 12, 47539 (2020)

[32] N. Li, F. Zhang, Y. Tang, J. Mater. Chem. A 6, 17889 (2018)

[33] J. Nai, X.W. Lou, Adv. Mater. 31, 1706825 (2019)

[34] P. Preetham, S. Mohapatra, S.V. Nair, D. Santhanagopalan, A.K. Rai, RSC Adv. 6, 38064 (2016)

[35] L. Ma, X.Y. Pei, D.C. Mo, Y. Heng, S.S. Lyu, Y.X. Fu, J. Mater. Sci.-Mater. Electron. 30, 5874 (2019)

[36] H. Xu, X. Wang, H. Liu, J. Wang, X. Dong, G. Liu, W. Yu, Y. Yang, H. Zhang, J. Mater. Sci. 53, 15631 (2018)

[37] Y. Zhang, W. Cao, Y. Cai, J. Shu, M. Cao, Inorg. Chem. Front. 6, 961 (2019)

[38] L.P. Wang, Y. Leconte, Z. Feng, C. Wei, Y. Zhao, Q. Ma, W. Xu, S. Bourrioux, P. Azais, M. Srinivasan, Z.J. Xu, Adv. Mater. 29, 1603286 (2017)

[39] P. Lu, Y. Sun, H. Xiang, X. Liang, Y. Yu, Adv. Energy Mater. 8, $1702434(2018)$ 